\title{
ADAPTASI PERIKANAN PUKAT CINCIN DI LAUT JAWA DAN IMPLIKASINYA TERHADAP PENGELOLAAN
}

\section{ADAPTATION OF PURSE SEINE FISHERY IN JAVA SEA AND IMPLICATIONS TO ITS MANAGEMENT}

\author{
Suherman Banon ${ }^{1}$ Atmaja, Duto ${ }^{2}$ Nugroho dan Suryanto ${ }^{2}$ \\ Peneliti pada Pusat Penelitian Pengelolaan Perikanan dan Konservasi Sumberdaya Ikan-Jakarta \\ 'Peneliti pada Balai Penelitian Perikanan Laut-Muara Baru, Jakarta \\ Teregistrasi I tanggal: 11 Februari 2013; Diterima setelah perbaikan tanggal: 27 Oktober 2014; \\ Disetujui terbit tanggal: 05 November 2014
}

\begin{abstract}
ABSTRAK
Usaha perikanan akan mengalami fluktuasi terkait dengan dinamika faktor alam, sedangkan nelayan mempunyai kemampuan yang lentur dan adaptif dalam kelangsungan usahanya. Tujuan utama makalah ini adalah membahas tentang kemampuan adaptasi perikanan purse seine untuk bertahan dari usaha perikanan tangkap. Pemetaan rekaman data sistem pemantauan kapal (VMS) purse seine pelagis kecil tahun 2012 dilakukan berdasarkan kriteria kecepatan kapal nol adalah waktu melakukan aktifitas penangkapan. Daerah penangkapan perikanan pukat cincin pada saat ini telah menyebar semakin luas, tidak terbatas di wilayah teritorial dan perairan nusantara, tetapi sudah sampai ke wilayah Samudera (ZEEI). Jumlah hari laut pada perikanan cantrang kurang dari sebulan memperoleh rata - rata pendapatan nelayan ABK hampir dua kali lipat dari pada ABK pukat cincin yang beroperasi lebih dari sebulan. Rotasi penggunaan alat tangkap di Laut Jawa adalah suatu kondisi yang muncul ke permukaan sebagai sinyal pergeseran populasi ikan dari karakteristik sumber daya yang multi-spesies. Fenomena hasil tangkapan yang tidak tercatat dan dilaporkan menyebabkan pendugaan stok ikan dengan akurat yang rendah akan menimbulkan ketidakpastian dalam penyusunan rekomendasi. Tersedianya sistem pemantauan kapal perlu didukung oleh kegiatan validasi hasil tangkapan yang didaratkan, untuk itu sangat perlu meningkatkan keterlibatkan enumerator dan observer di atas kapal serta penguatan sistem log-book yang sedang berjalan.
\end{abstract}

KATA KUNCI: Adaptasi, perikanan, pukat cincin, Laut Jawa, implikasi, pengelolaan

\section{ABSTRACT}

The fishing business will fluctuate as a result of high connectivity with the dynamic and nature of environmental factors, in the other side, experience fishers have flexible and adaptive capabilities in order to sustain their business. The objective of this paper is to describe the purse seine fishery adaptability to survive from long term fishing. Plotting data on recorded vessel monitoring system (VMS) of small pelagic purse seine in 2012 were applied based on the criteria of the zero vessel's speed as a baseline on fishing activity. Currently, fishing ground of purse seine fisheries been spread more widely, not limited in the territory and waters of the archipelago, but it goes up to the Ocean Region (ZEEI) with day at sea of months. A competitive demersal Danish fishery with average day at sea less than a month is more attractive to fishers. They obtain the average income per crew nearly doubled of working at purse seine with day at sea of more than a month. Rotation on using different type of fishing gears in the Java Sea is a condition that comes to face. This common situation as a signal of shift of having beneficiary of multi-species fish populations. The phenomenon of unreported catches could generate inaccurate estimation of fish stocks and the uncertainty in the management measures to be adviced. Strengthening enumerator and onboard observer program could significantly contribute to validate process of the catch landed,

KEYWORDS: Adaptation, fishing, purse seine, Java Sea, implications, management

\section{PENDAHULUAN}

Usaha perikanan akan mengalami siklus nonsimetris (cycle asymmetry) atau akan mengalami fluktuasi akibat faktor alam. Pada saat hasil tangkapan yang baik, nelayan/pengusaha akan terus menambah modal (kapal dan peralatan), sedangkan modal tidak mudah ditarik kembali pada saat usaha perikanan sedang mengalami periode kurang menguntungan (Cope, 1986 dalam Fauzi, 2005). Mathiesen (2005) menyatakan bahwa kepandaian memilih keputusan interaktif dan berkelanjutan nelayan dapat dibagi menjadi dua alasan yang terkait: (1) jangka pendek (trip)-nelayan melakukan di mana, kapan dan

Korespondensi penulis.

Balai Penelitian Perikanan Laur, Muara Baru-Jakarta

Jl.Muara Baru Ujung, Komp. PPS Nizam Zachman, Jakarta-Utara 
bagaimana caranya untuk menangkap ikan (taktik penangkapan). (2) jangka panjang - nelayan menetapkan strategi untuk bagaimana dan kapan untuk menginvestasikan modalnya dalam usaha penangkapan. Pergeseran spesies target juga dapat dianggap sebagai strategi, untuk mengurangi ketidakpastian hasil tangkapan (Christensen \& Raakjaer 2006). Nelayan mempunyai kemampuan yang fleksibel dan adaptif dalam usaha perikanan, karena terus menerus dihadapkan pada suatu situasi perubahan lingkungan eksternalnya, seperti cuaca, perubahan harga ikan, akses terhadap sumber daya dan regulasi.

Nelayan memanfaatkan pengetahuan mereka tentang spesies ikan, mengubah distribusi upaya penangkapan dari waktu ke waktu dan ruang. ditanggapi para pelaku usaha dengan cara merubah taktik dan strategi penangkapan serta perpindahan daerah penangkapan maupun penyesuaian teknologi pada sasaran tangkap yang dituju (Atmaja, 2008; Atmaja et al., 2012).

Makalah ini membahas tentang kemampuan adaptasi perikanan pukat cincin untuk bertahan dari usaha perikanan tangkap, dalam menghadapi perubahan kondisi perikanan melalui adaptasi individu nelayan/pengusaha. Materi disusun berdasarkan penelusuran hasil penelitian yang telah dilaksanakan oleh Balai Penelitian Perikanan Laut, dilengkapi kajian pustaka dan pemetaan rekaman data sistem pemantauan kapal (VMS) pukat cincin pelagis kecil tahun 2012 berdasarkan kriteria kecepatan kapal nol. Kriteria ini menggambarkan kapal berada di pelabuhan, sedang pencarian ikan di daerah penangkapan atau berlindung.

\section{BAHASAN \\ Rotasi Pemanfaatan SDI}

Dalam kondisi penurunan stok ikan yang diikuti dengan kenaikan harga bahan bakar minyak (BBM) sejak tanggal 1 Oktober 2005 telah menyebabkan penurunan aktivitas sebagian besar kapal pukat cincin di Pekalongan dan Juwana, lebih dari 50\%, kapal hanya bertambat di Pelabuhan. Tanggapan adaptif pengusaha sebagai alternatif untuk bertahan dari usaha penangkapan, mereka melakukan relokasi usaha perikanannya secara swakarsa. Sementara pengusaha tidak merelokasi usahanya, melakukan diversifikasi usaha dengan mengganti perangkat penangkapannya, dengan mengalihkan sebagian kapal penangkap menjadi kapal penangkap cumi-cumi dan berganti alat tangkap dengan menggunakan jaring cantrang (Atmaja, 2008).
Upaya pembatasan usaha tidak sejalan dengan harapan program pembangunan perikanan, karena sebagian besar (lebih dari 95\%) armada penangkapan masih didominasi kapal berukuran di bawah 30 GT. Sebagai contoh di Laut Jawa (WPP 712), jumlah kapal berbobot $\leq 10$ GT mencapai sekitar $94 \%$, armada kapal berbobot > 10 - 30 GT sekitar 4\% dan armada kapal berbobot > 30 GT hanya sekitar $2 \%$.

Secara nasional kebijakan pembangunan perikanan menekankan peningkatan produksi, jumlah nelayan dan produktivitas, dan pendapatan rendah para nelayan diyakini hanya dapat dilakukan melalui peningkatan kemampuan kapal dan alat penangkapan. Selain itu, konsep "buy back" tidak dikenal di Indonesia, sementara kapal penangkap ikan tidak mudah dialokasikan untuk penggunaan di luar perikanan. Dengan demikian, pertimbangan dilema sosial menjadi pilihan kebijakan regulasi perikanan tangkap melalui peralihan spesies target dan diversifikasi usaha penangkapan. Hal lain, bagi pengusaha dan nelayan yang memiliki sejarah panjang tidak mudah keluar dari usaha perikanan. Mereka akan terus berjalan dengan berbagai strategi meskipun harus menghadapi resiko dalam bentuk apapun. Rotasi penggunaan alat tangkap di Laut Jawa adalah suatu kondisi yang muncul ke permukaan sebagai sinyal pergeseran populasi ikan dari karakteristik sumber daya yang multi-spesies.

\section{Perubahan Target SDI Pelagis Kecil ke Pelagis Besar}

Keberlanjutan perikanan pukat cincin pada saat ini karena adanya penyesuaian terhadap daerah penangkapan yang semakin luas, tidak terbatas di wilayah teritorial dan perairan nusantara, tetapi sudah sampai ke wilayah Samudera (ZEEI). Pada pertengahan tahun 2003, delapan kapal pukat cincin yang berasal dari Pontianak dan Pekalongan melakukan relokasi usaha perikanan secara swakarsa ke Bitung (Sulawesi Utara), kemudian pada tahun 2006 diikuti oleh 35 kapal regrestrasi Jakarta, Pekalongan dan Semarang. Beberapa armada kapal pukat cincin lainnya bergerak ke perairan Bengkulu (perairan Barat Sumatera) untuk mengeksploitasi sumber daya ikan pelagis besar. Realokasi kapal pukat cincin tersebut bukan sebagai rancangan program pembatasan keikutsertaan dalam usaha perikanan pelagis di ketiga wilayah pengelolaan perikanan, WPP 712 (Laut Jawa), WPP 711 (Selat Karimata dan Laut Cina Selatan), WPP 713 (Selat Makassar dan Laut Flores), tetapi lebih disebabkan peluang bisnis dan tingkat keuntungan, serta mudahnya perizinan pindah WPP. 
Hasil pemantauan kapal perikanan (VMS, vessel monitoring syestem) dari rekaman data VMS pukat cincin pelagis kecil pada tahun 2012 memperlihatkan aktivitas penangkapan telah menyebar ke Samudera Hindia (ZEEI) dan Samudera Pasifik (Gambar 1). Jumlah hari di laut yang beroperasi di Samudera Hindia berkisar antara 23-109 hari dengan rata-rata sekitar 55 hari, sedangkan yang beroperasi di Laut Maluku berkisar 60 - 92 hari dengan rata-rata berkisar 80 hari, Sementara.yang beroperasi di Paparan Sunda berkisar antara $73-134$ hari dengan rata-rata berkisar 94 hari (Atmaja, et al. 2012).

Pada umumnya perikanan pukat cincin terkait dengan rumpon laut dalam (payaos) menargetkan tuna. Rumponisasi perikanan laut lepas (distant waters fishery) memperjelas ketidakpastian efektivitas sebagian besar pendekatan pendugaan dan pengelolaan perikanan, artinya estimasi sumber daya ikan dan jumlah tangkapan yang diperbolehkan dari penetapan KKP tidak menjadi pertimbangan tetapi lebih berdasarkan fleksibilitas dan kemampuan adaptasi dari pengusaha/nelayan dalam mengatisipasi kondisi stok ikan yang dialamimya.
Teknologi "cold chain system" telah digunakan untuk penanganan ikan mulai di atas kapal sampai ke tingkat perusahaan berupa ikan beku (frozen). Sebaliknya kapal yang beroperasi di perairan Paparan Sunda masih tetap mentargetkan ikan pelagis kecil, dan hasil tangkapan berupa produk ikan asin. Sementara sebagian besar hasil tangkapan ikan segar telah dijual di laut (Atmaja et al. 2012; Natsir \& Atmaja 2013).

\section{Diversifikasi Usaha ke Perikanan Cumi-cumi}

Sejak tahun 2002 perikanan cumi-cumi mulai berkembang di beberapa sentra - sentra pendaratan ikan, seperti Indramayu, Juwana, Jakarta, Pontianak dan Benoa. Perikanan ini menggunakan alat tangkap jaring cumi (bouke ami dan cast net), dengan alat bantu cahaya (fishing light attractor) dengan daya 1000-1500 watt sebanyak 24-90 buah sebagai pengumpul ikan. Dari tiga lokasi sentra perikanan, sebagian besar kapal cumi-cumi berada di Jakarta (Tabel 1).

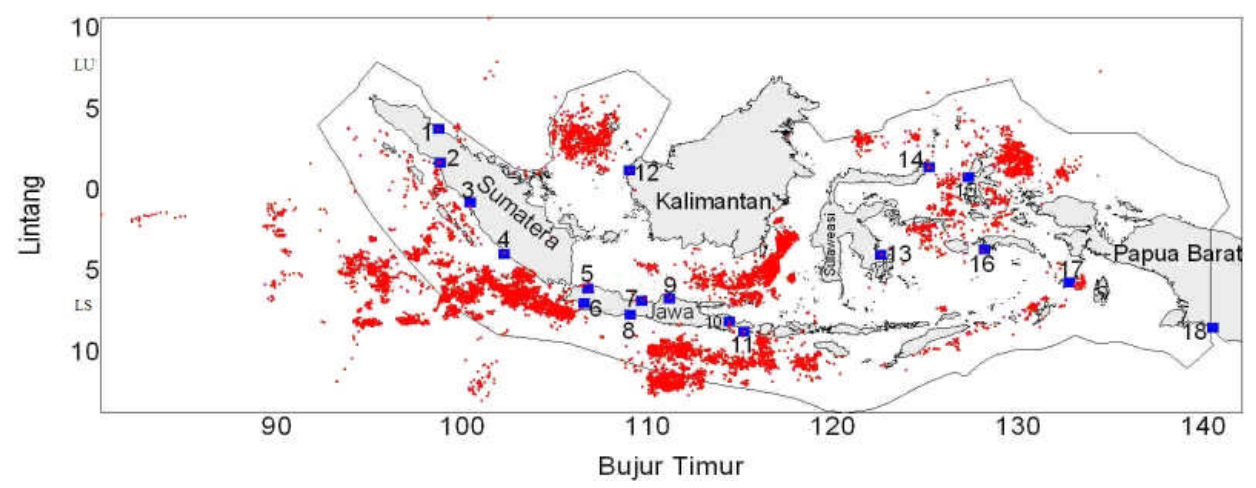

Gambar 1. Aktivitas penangkapan perikanan pukat cincin pelagis kecil berdasarkan atas data VMS (keterangan: 1 Belawan, 2 Sibolga, 3 Bungus, 4 Bengkulu, 5 Jakarta, 6 Pelabuhan Ratu, 7 Pekalongan, 8 Cilacap, 9 Juwana, 10 Banyuwangi, 11 Benoa, 12 Pemangkat, 13 Kendari, 14 Bitung, 15 Ternate, 16 Ambon, 17 Tual, 18 Merauke).

Figure 1. Fishing activities of purse seiner's small pelgic based on VMS data (remarks: 1 Belawan, 2 Sibolga, 3 Bungus, 4 Bengkulu, 5 Jakarta, 6 Pelabuhan Ratu, 7 Pekalongan, 8 Cilacap, 9 Juwana, 10 Banyuwangi, 11 Benoa, 12 Pemangkat, 13 Kendari, 14 Bitung, 15 Ternate, 16 Ambon, 17 Tual, 18 Merauke).

Tabel 1. Jumlah kapal cumi-cumi menurut lokasi tahun 2010

Table 1. The numbers of squid vessel by location in 2010

\begin{tabular}{|l|l|l|l|l|}
\hline \multicolumn{2}{|c|}{ Jakarta } & \multicolumn{2}{c|}{ Cirebon } & Juwana \\
\hline GT $<30$ & GT $>30$ & GT $<30$ & GT $>30$ & GT $<30$ \\
\hline 295 & 141 & 28 & 15 & 31 \\
\hline
\end{tabular}

Sumber: Atmaja (2013) 
Berdasarkan atas rekaman data sistem pemantauan kapal (VMS,) memberikan gambaran yang lebih rinci daerah penangkapan, jalur lintasan kapal (vessel track) setiap trip dan aktivitas tawur. Daerah penangkapan telah menyebar ke WPP 712 (Laut Jawa), WPP 711 (Selat Karimata dan Laut Cina Selatan), WPP 718 (Laut Aru dan Laut Arafuru) (Gambar 2). Jumlah hari di laut yang beroperasi di Paparan Sunda berkisar antara $40-58$ hari dengan rata-rata sekitar 52 hari, sedangkan yang beroperasi di Laut Aru dan L. Arafuru mereka umumnya dikontrak selama satu tahun. Sementara kapal cumi-cumi di Juwana hanya beroperasi di Utara Pulau Bawean Kalimatam Selatan pada saat gelap bulan dengan durasi di laut selama 20 - 25 hari (Atmaja, 2013).

Hasil tangkapan dominan berupa cumi-cumi dan tenggiri merupakan produk perikanan ekonomis tinggi. Alat yang digunakan untuk menangkap cumi-cumi adalah jaring cumi sedangkan untuk menangkap tenggiri adalah pancing (hand lines). Sebagian besar kapal telah menggunakan metode pembekuan cepat (plate freezing atau quick freezing). Kecuali di Juwana metode pembekuan tersebut mulai diterapkan pada kelompok nelayan binaan usaha penangkapan nelayan bakti.

\section{Diversifikasi Usaha ke Perikanan Cantrang}

Perubahan kapal pukat cincin menjadi cantrang telah berlangsung sejak tahun 2003, terutama pada pukat cincin yang berpangkalan di Pelabuhan Perikanan Pantai Tegal. Pada kondisi hasil tangkapan perikanan pukat cincin semakin menurun, penggunaan alat tangkap cantrang lebih menguntungkan bagi nelayan Jawa Tengah. Kapal cantrang melaut hanya sepertiga (kurang dari satu bulan) dibandingkan kapal pukat cincin. Dari 12 trip dari dua kapal cantrang contoh di Juwana pada tahun 2009 , rata rata pendapatan real nakhoda sebesar Rp. 5 juta, motoris sebesar Rp 3,5 juta dan ABK (pendega) sebesar Rp. 1,5 juta dan disparitas pendapatan yang diterima oleh masing-masing bagian nelayan (pemilik, nahkoda, dan $A B K$ ) sangat tinggi sekali, terutama bagi hasil yang diterima oleh ABK (Gambar 3). Hasil penelitian Sismadi (2006) menunjukkan rata - rata pendapatan nelayan kapal pukat cincin dengan rata rata 46,5 hari per trip, yaitu: nahkoda dan motoris relatif sama dengan kapal cantrang masing-masing sebesar Rp 5.1 juta dan sebesar Rp 1.6 juta, sedangkan ABKnya hanya memperoleh pendapatan sebesar Rp. 0,8 juta (sekitar $71 \%$ dari distribusi pendapatan ABK kurang dari Rp. 1 juta).

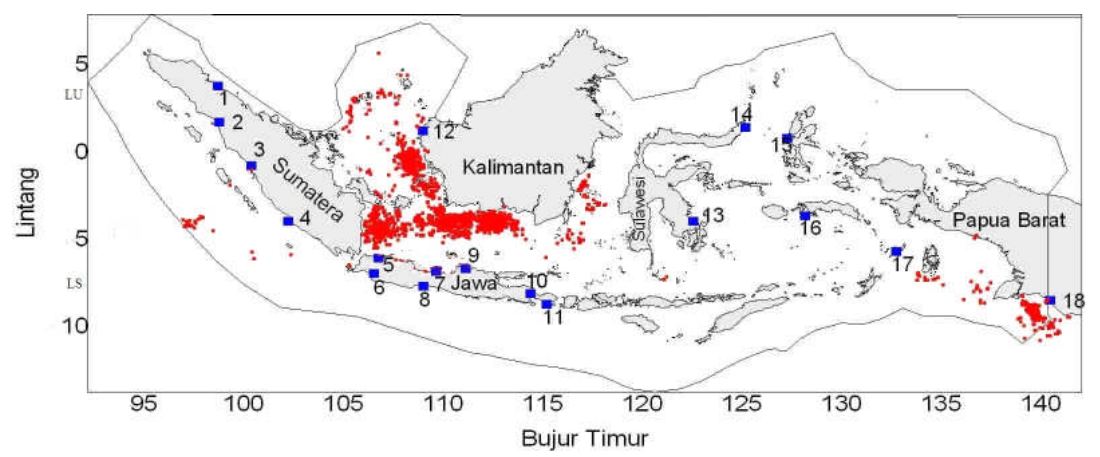

Gambar 2. Penyebaran aktivitas penangkapan kapal cumi-cumi berasal dari pukat cincin.

Figure 2. Distribution fishing activities the squid vessels delived from purse seine.

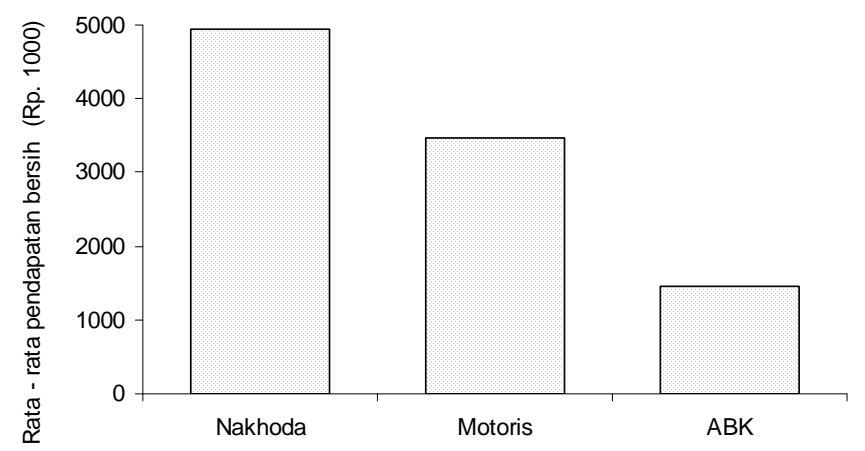

Gambar 3. Pendapatan real ABK dari hasil bagi hasil.

Figure 3. Real income of crews from the profit-sharing. 
Tabel. 2. Rata-rata jumlah hari operasi kapal pukat cincin dan cantrang yang berasal dari kapal pukat cincin pada tahun 2009

Table. 2. The average days at sea of purse seiners and danish seiners which comes from purse seiners in 2009

\begin{tabular}{lccc}
\hline & Kapal pukat cincin (Pekalongan)/ & \multicolumn{2}{c}{ Cantrang/ } \\
& Purse seine (Pekalongan) & Demersal Danish seine \\
\hline & (hari)/days & (hari)/days & ABK/Crewa \\
Rata-rata & 83,6 & 28,5 & 16,1 \\
SD & 21,8 & 9,4 & 126 \\
N & 498 & & 2,5 \\
\hline
\end{tabular}

Dengan demikian pada perikanan cantrang waktu melaut yang lebih singkat, pendapatan yang diperoleh ABK cantrang hampir dua kali lipat dari pada ABK pukat cincin. Berdasarkan kapal yang mendaratkan hasil tangkapan di TPI Juwana pada tahun 2008 dan 2009 tercatat sekitar 63 kapal pukat cincin berbobot di atas 30 GT telah berganti menggunakan alat tangkap cantrang (Atmaja, 2009). Umumnya kapal motor yang berbobot lebih besar $20 \mathrm{GT}$, sudah keluar dari pantai utara Pulau Jawa, daerah penangkapan telah menyebar ke hampir seluruh Laut Jawa dari Selatan Belitung dan Selatan Kalimantan sampai Selat Makassar (Ernawati et al. 2011; Atmaja \& Nugroho, 2012).

Perkembangan perikanan cantrang selanjutnya lebih untuk memenuhi pasokan bahan baku komoditi ekspor yang dimiliki oleh perusahaan Korea. Hasil pengamatan di lapangan menunjukkan sebagian besar hasil tangkapan cantrang diserap sebagai bahan baku surimi dan filet, terutama beberapa spesies ikan, seperti ikan kuniran (Upeneus spp), coklatan (Scolopsis taeniopterus), kurisi (Nemipterus spp), Swangi/demang (Priacanthus spp) dan gulamah/ tigawaja (Scianidae). Berdasarkan komposisi hasil tangkapan, kelima jenis ikan tersebut mencapai hampir $65 \%$, sedangkan untuk kebutuhan protein ikan bagi masyarakat lokal kurang dari $20 \%$, dan sisanya digunakan sebagai pakan ternak bebek. Dari kenyataan ini, subsidi BMM secara tidak langsung dinikmati oleh perusahaan asing/Korea. Pada sisi lain kekhawatiran akan mengganggu dan memberikan kontribusi terhadap ketahanan pangan dan kedaulatan pangan atau kemandirian pangan (food security \& food sovereignity) bagi masyarakat lokal diabaikan.

\section{Implikasi Pengelolaan Perikanan}

Rotasi eksploitasi dan perluasan daerah penangkapan berimplikasi pada penurunan jumlah kapal mapun aktivitas penangkapan pada perikanan pukat cincin semi industri di Paparan Sunda. Selama 15 tahun aktivitas penangkapan menurun tajam dari rata-rata trip/kapal sekitar 8 trip/kapal pada tahun 1995 menjadi sekitar 2 - 3 trip/kapal pada tahun 2010.
Pada tahun 2009, jumlah kapal aktif di Pekalongan hanya tersisa sekitar $30 \%$ dibandingkan pada tahun 2005, sedangkan bila dibandingkan jumlah tertinggi pada tahun 1995 berada pada kisaran 18-19\%. (Atmaja et al. 2011b). Sebaliknya kemampuan tangkap terus meningkat dengan investasi tambahan input melalui penerapan metode pembekuan cepat (sharp freezing) dan penambahan daya lampu. Pada tahun 2011, dengan menambah jumlah lampu bolham dengan daya 2000 watt sebanyak 20 buah. Kini kapal pukat cincin telah menggunakan paling sedikitnya 40000 - 70000 watt (Sadhotomo \& Atmaja, 2012). $\mathrm{Hal}$ ini telah menyebabkan perang cahaya antar perikanan pukat cincin dan perikanan cumi-cumi tidak dapat dihindari, sedangkan rumponisasi pukat cincin di Samudera Hindia dikhawatirkan berdampak negatif terhadap rawai tuna, terutama pada saat olah gerak kapal rawai tuna kerapkali terganggu.

Posisi estimasi tawur dan data harian observer mempertegas bahwa perikanan laut lepas (distantwater fishery) didukung oleh rumpon laut-dalam (payaos) (Atmaja et. al. 2011a). Dengan demikian, rumponisasi perikanan laut lepas pada perikanan pukat cincin berimplikasi terhadap upaya perubahan pengelolaan perikanan dari common property right menjadi private property atau paling tidak "a private property resource exists in a common property regime". Secara tidak langsung telah menerapkan kebijakan berdasarkan atas alokasi hak eksklusif penangkapan ikan.

Pada kasus perikanan cantrang, situasi lapangan menunjukkan baik jumlah kapal maupun teknologi penanganan hasil tangkapan terus meningkat, kapal cantrang baru telah dipersiapkan menggunakan metode pembekuan cepat. Sementara pada kapal berbobot lebih besar 30 GT untuk menghadapi tantangan dan ancaman razia yang dilakukan oleh petugas TNI AL dan Polisi Air dan Udara (Pol Airud). Nelayan menanggapinya dengan penyamaran mengunakan pancing rawai dasar atau pukat cincin. Pembatasan input melalui territorial use right of fisheries yang menekankan penggunaan fishing right (hak memanfaatkan sumber daya perikanan) dalam 
suatu wilayah tertentu dalam yurisdiksi (UU No 27 Tahun 2007) yang jelas tidak berjalan, karena pertimbangan implikasi sosial lebih dominan (Atmaja \& Nugroho, 2012).

Dari pengamatan di lapangan, fenomena unreported baik disreported maupun misreported semakin besar terjadi. Pada kapal pukat cincin, hasil tangkapan yang dilelang hanya berkisar antara 30$50 \%$ dari hasil tangkapan sebenarnya, sisanya telah dijual di laut (Atmaja et. al., 2011b). Dari aktivitas penangkapan di Samudera Hindia bagi ikan yang beruaya jauh (highly migratory fish stocks) telah terjadi unreported, karena hasil tangkapan yang didaratkan di Pelabuhan Perikanan Samudera Nizam Zachman Jakarta dan di Perlabuhan Banyuwangi tidak dilakukan pelelangan langsung (sistem takahan).

Pada perikanan jaring cumi-cumi, hampir di seluruh tempat pendaratan ikan, sebagian besar hasil tangkapan dari kapal cumi-cumi tidak melalui proses lelang langsung, hasil tangkapan dalam bentuk ikan beku langsung diangkut ke gudang pendingin (cold storage) (Atmaja, 2013). Pada perikanan cantrang, berdasarkan catatan Satuan Kerja PSDKP Tegal selama kurun waktu Juni 2011 - Maret 2012, hasil tangkapan cantrang hanya tercatat kurang dari sepertiganya apabila dibandingkan dengan data hasil observer, yaitu hasil tangkapan/trip berkisar 6,3-8,5 ton, sedangkan hasil observer dari kapal contoh berkisar antara 22,72 ton - 30,42 ton (Ernawati et al. 2011).

Fenomena peningkatan bertahap upaya penangkapan (technological creep), tinggal di laut berbulan-bulan dan dapat singgah lebih dari satu pelabuhan semakin sulit mendefinisikan upaya penangkapan yang relevan. Selain itu perilaku rendahnya tanggung jawab pelaporan hasil tangkapan menunjukkan semakin kompleksnya permasalahanpermasalahan pendataan perikanan. Situasi tersebut akan menyebabkan tidak hanya pendugaan stok ikan tidak akurat dan ketidakpastian dalam nasihat, tetapi juga penetapan sistem tutup - buka perizinan akan menghadapi kendala, Dalam Peraturan Menteri KP No. PER 12/MEN/2009 tentang usaha perikanan tangkap, Pasal 30 (1) dikemukakan bahwa "jangka waktu berlakunya SIUP sebagaimana dimaksud dalam Pasal 29 (1) akan dievaluasi setiap dua tahun atau apabila ketersediaan daya dukung sumber daya ikan dalam kondisi semakin menipis". Perbaikanperbaikan dan terobosan dari sistem pendataan diusulkan melalui validasi hasil tangkapan dengan meningkatkan keterlibatkan enumerator dan observer di atas kapal. Data dan informasi VMS dimanfaatkan secara optimal untuk upaya penangkapan nominal (trip dan durasi lama di laut) dan pelacakan armada penangkapan ikan.

\section{KESIMPULAN}

1) Kemampuan adaptasi pengusaha/nelayan perikanan pukat cincin pasca penurunan stok ikan pelagis di Laut Jawa di luar dugaan, rumponisasi perikanan lepas pantai dan rotasi alat tangkap, sebagai alternatif baru untuk bertahan dari usaha penangkapan.

2) Dengan waktu melaut yang lebih singkat (kurang dari satu bulan), pendapatan ABK cantrang hampir dua kali lipat dari pada ABK pukat cincin yang melalut hampir satu setengah bulan. Hal ini mendorong ABK pukat cincin, terutama di Tegal dan Juwana lebih memilih menjadi ABK kapal cantrang.

3) Permintaan kebutuhan pasokan bahan baku perusahaan asing, maka subsidi BMM secara tidak langsung dinikmati oleh orang lain dan ketahanan keamanan pangan terabaikan

\section{REKOMENDASI}

Pemahaman faktor yang mempengaruhi pola spasial dan temporal upaya penangkapan berguna untuk rencana pengelolaan masa depan, untuk alokasi upaya penangkapan, pengembangan strategi manajemen, dan memodelkan reaksi perikanan terhadap rencana pengelolaan. Data dan informasi VMS dimanfaatkan secara optimal untuk upaya penangkapan nominal (trip dan durasi lama di laut) dan untuk studi distribusi spasial dan temporal kegiatan penangkapan. Perbaikan-perbaikan sistem pendataan diusulkan melalui validasi hasil tangkapan dengan meningkatkan keterlibatkan enumerator dan observer di atas kapal.

\section{DAFTAR PUSTAKA}

Atmaja, S.B, 2008. Sumber daya ikan pelagis kecil dan Dinamika perikanan pukat cincin di Laut Jawa dan sekitarnya. BRPL. PRPT. BRKP. 100p.

Atmaja S.B. 2009. Dinamika Perikanan Pukat Cincin sebagai Indikator Perilaku antar Wilayah Pengelolaan Perikanan. Seminar Hasil Pelaksanaan Penelitian bagi Peneliti dan Perekayasa Sesuai Prioritas Nasional Tahun 2009. Jakarta. 15 - 16 Desember 2009.

Atmaja, S.B. 2013. Perkembangan Perikanan CumiCumi di Sentra Pendaratan Ikan Utara Pulau Jawa. JPPI 19 (1): 31-38. 
Atmaja; S.B. \& D. Nugroho, 2011. Upaya - Upaya Pengelolaan Sumber daya ikan yang Berkelanjutan di Indonesia. JKPI 3 (2): 101 - 113.

Atmaja; S.B. \& D. Nugroho, 2012. Distribusi Spasial Upaya Penangkapan Kapal Cantrang dan Permasalahannya di Laut Jawa. JPPI 18 (4): 239247.

Atmaja; S.B., M. Natsir \& Adi Kuswoyo. 2011a Analisis Upaya Efektif dari data VMS (Vessel Monitoring System) dan Produktivitas Pukat Cincin Semi Industri di Samudera Hindia. JPPI 17 (3): 177-184.

Atmaja; S.B., D. Nugroho \& M. Natsir, 2011b. "Respons Radikal" Kelebihan Kapasitas Penangkapan Armada Pukat Cincin Semi Industri di Laut Jawa. JPPI 17 (2): 115-129.

Atmaja S.B., M. Natsir \& B. Sadhotomo, 2012. Dinamika Spasial Perikanan Pukat cincin di Laut Jawa dan Samudera Hindia. JPPI 18 (2): 69-7.

Christensen, A. S. \& J. Raakjaer. 2006. Fishermen's tactical and strategic decisions: a case study of Danish demersal fisheries. Fisheries Research 81:258-267.
Fauzi, A. 2005. Kebijakan perikanan dan kelautan, isu, sistesis dan gagasan. Gramedia. 187p.

Ernawati, T., Nuruludin \& S.B. Atamaja. 2011. Produktivitas, komposisi hasil tangkapan dan daerah penangkapan jaring cantrang yang berbasis di PPP Tegalsari, Tegal. JPPI Volume 17 (3); 193200.

Mathiesen, C., 2005. Analytical framework for studying fishers' behaviour and adaptation strategies. Institute of Fisheries Management and Coastal Community Development (IFM), Denmark.

Natsir M.\& S.B Atmaja, 2013. Aktivitas Penangkapan Individu Kapal Pukat cincin di Laut Maluku: Sistem Pemantauan Kapal dan Observer. JPPI 19 (1): 1724.

Sadhotomo, B. \& S.B. Atmaja, 2012. Sintesa Kajian Stok ikan Pelagis kecil di Laut Jawa. JPPI 18 (4): 267-283.

Sismadi, 2006. Analisis efisiensi penggunaan input alat tangkap pukat cincin di koata Pekalongan. Tesis. Program Studi Magister IImu Ekonomi dan Studi Pembangunan. Pascasarjana UNDIP Semarang 111p. 